\title{
EFEITO DOS REGULADORES DE CRESCIMENTO DICAMBA E PICLORAM NA EMBRIOGÊNESE SOMÁTICA EM Eucalyptus grandis ${ }^{1}$
}

\author{
Miranda Titon ${ }^{2}$, Aloisio Xavier ${ }^{3}$, Wagner Campos Otoni ${ }^{4}$ e Sérgio Yoshimitsu Motoike 5
}

\begin{abstract}
RESUMO - Este trabalho objetivou avaliar o efeito das auxinas dicamba e picloram na indução de embriogênese somática em embriões zigóticos maduros, cotilédones e hipocótilos de Eucalyptus grandis. Os calos foram induzidos em meio de cultura MS contendo dicamba $\left(0,25 ; 0,5 ; 1,0 ; \mathrm{e} 2,0 \mathrm{mg} \mathrm{L}^{-1}\right)$ ou picloram $(0,5 ; 1,5 ; 5,0$; e $10,0 \mathrm{mg} \mathrm{L}^{-1}$ ). Nos tratamentos com $0,5 \mathrm{mg} \mathrm{L}^{-1}$ de dicamba ou 5,0 e $10,0 \mathrm{mg} \mathrm{L}^{-1}$ de picloram, em explantes cotiledonares, foram observadas estruturas semelhantes a embriões somáticos em diferentes estádios de desenvolvimento. A análise histológica confirmou tratar-se de estruturas independentes, com um sistema vascular fechado, evidenciando se tratar de embriões somáticos.
\end{abstract}

Palavras-chave: Micropropagação, cultura de tecidos e propagação clonal.

\section{SOMATIC EMBRYOGENESIS IN Eucalyptus grandis: EFFECT OF GROWTH REGULATORS DICAMBA AND PICLORAM}

\begin{abstract}
The objective of this paper was to evaluate the effect of dicamba and picloram on the induction of somatic embryogenesis in mature zygotic embryos, cotyledons and hypocotyls of Eucalyptus grandis. Callus induction was obtained in MS culture medium with dicamba $\left(0.25 ; 0.5 ; 1.0\right.$ and $\left.2.0 \mathrm{mg} \mathrm{L}^{-1}\right)$ or picloram $\left(0.5 ; 1.5 ; 5.0\right.$ and $\left.10.0 \mathrm{mg} \mathrm{L}^{-1}\right)$. Treatments of cotyledonary explants with dicamba $\left(0.5 \mathrm{mg} \mathrm{L}^{-1}\right)$ or picloram (5.0 and $10.0 \mathrm{mg} \mathrm{L}^{-1}$ ) resulted in structures similar to somatic embryos, which appeared in different development stages. The histological analysis confirmed the presence of independent structures with an independent vascular system, suggesting that the structures are somatic embryos.
\end{abstract}

Keywords: Micropropagation, tissue culture and clonal propagation.

\section{INTRODUÇÃO}

Na busca de novas tecnologias para o constante aprimoramento da clonagem de Eucalyptus, a embriogênese somática tem despertado interesse especial por parte de instituições de pesquisa e empresas florestais brasileiras que possuem avançados programas de melhoramento genético e de clonagem.

A embriogênese somática pode ser descrita como o processo pelo qual células somáticas desenvolvem estruturas semelhantes a embriões zigóticos, por meio de uma seqüência ordenada de estádios embriogênicos característicos, sem ocorrência de fusão dos gametas (GUERRA et al., 1999; JIMÉNEZ, 2001). Durante o seu desenvolvimento, embriões somáticos passam por estádios similares àqueles observados na embriogênese zigótica, caracterizandose como estrutura bipolar sem nenhuma conexão vascular com o tecido materno (DURZAN, 1988; VICIENT e MARTINEZ, 1998).

\footnotetext{
${ }^{1}$ Recebido em 11.09.2006 e aceito para publicação em 04.02.2007.

${ }^{2}$ Programa de Pós-Graduação em Ciência Florestal da Universidade Federal de Viçosa - UFV. E-mail: <titonmiranda@ yahoo.com.br>.

${ }^{3}$ Departamento de Engenharia Florestal da UFV. E-mail: <xavier@ufv.br>.

${ }^{4}$ Departamento de Biologia Vegetal da UFV. E-mail: <wotoni@ufv.br>.

${ }^{5}$ Departamento de Fitotecnia da UFV. E-mail: <motoike@ufv.br>.
} 
Dentre as principais aplicações na área florestal, está o uso de embriões somáticos na propagação em massa de Eucalyptus, especialmente para aquelas espécies ou clones de difícil enraizamento, proporcionando uma alternativa ao enraizamento de estacas e de brotações micropropagadas (BAJAJ, 1995). Embora o Eucalyptus apresente altas taxas de multiplicação por gemas axilares, estudos realizados com outras espécies florestais indicam o potencial de obtenção de taxas muito maiores com a embriogênese somática. A técnica apresenta também vantagens adicionais, como redução no número de estádios de cultura, redução de trabalho e custo, rapidez e facilidade para a produção em larga escala em meio líquido utilizando biorreatores (HAINES, 1994; WATT et al., 1999), bem como a possibilidade de encapsulamento e armazenamento de embriões como sementes sintéticas (BAJAJ, 1995). Além disso, a embriogênese somática constitui-se numa técnica básica para outras aplicações biotecnológicas, incluindo transformação genética, hibridação somática e preservação de germoplasma (VICIENT e MARTINEZ, 1998).

Nas últimas décadas, a formação de embriões somáticos ou estruturas embriogênicas tem sido reportada para algumas espécies do gênero Eucalyptus, como E. grandis (WATT et al., 1991; MAJOR et al., 1997), E. dunnii (TERMIGNONI et al., 1996), E. nitens (RUAUD et al., 1997; BANDYOPADHYAY et al., 1999; BANDYOPADHYAY e HAMILL, 2000), E. urophylla (TIBOK et al., 1995; ARRUDA et al., 2000), E. citrodora (MURALIDHARAN e MASCARENHAS, 1987; 1995) e E. globulus (NUGENT et al., 2001; BANDYOPADHYAY et al., 1999; PINTO et al., 2002). No entanto, a maioria dos trabalhos relata a inexistência de um protocolo eficiente de regeneração de Eucalyptus por embriogênese somática, uma vez que ainda existem problemas básicos a serem solucionados, como o número reduzido de embriões obtidos e a baixa taxa de conversão dos embriões em plantas.

Esforços para induzir embriogênese somática têm sido descritos para muitas espécies de interesse econômico, em que as metodologias utilizadas envolvem mudanças no meio de cultura, estabelecimento de diferentes tipos e concentrações de reguladores de crescimento e outras condições de cultura, como a densidade de células, nutrientes e iluminação.

Em relação ao fator regulador de crescimento, as auxinas dicamba (ácido 3,6-dicloroanísico) e picloram (ácido 4-amino-3,5,6-tricloropicolínico), como indutoras de embriogênese somática, têm sido investigadas com frequiência em espécies agronômicas. A formação direta de embriões somáticos em Paspalum scrobiculatum ocorreu com a utilização de altos níveis de picloram, isoladamente ou em combinação com cinetina (KAUR e KOTHARI, 2004). Picloram também foi efetivo na obtenção de embriogênese somática repetitiva em Arachis hypogaea (LITTLE et al., 2000). Dicamba promoveu a formação de embriões somáticos em trigo (GEORGE, 1993), Musa (LEE et al., 1997) e Arachis hypogaea (LITTLE et al., 2000).

Alguns relatos têm indicado que calos embriogênicos podem ser induzidos em Eucalyptus em meio contendo 1-5 $\mathrm{mg} \mathrm{L}^{-1}$ de 2,4-D (ácido 2,4diclorofenoxiacético) ou $0,5-5 \mathrm{mg} \mathrm{L}^{-1}$ de ANA (ácido $\alpha$-naftalenoacético). No entanto, investigações sobre o efeito de dicamba e picloram na embriogênese somática se restringem aos trabalhos com E. globulus (NUGENT et al., 2001; PINTO et al., 2002) e E. urophylla (ARRUDA et al., 2000).

Neste trabalho, objetivou-se avaliar o efeito das auxinas dicamba e picloram na indução de embriogênese somática em embriões zigóticos maduros, cotilédones e hipocótilos de Eucalyptus grandis.

\section{MATERIAL E MÉTODOS}

Os experimentos foram conduzidos no Laboratório de Cultura de Tecidos II do Instituto de Biotecnologia Aplicada à Agropecuária (BIOAGRO), da Universidade Federal de Viçosa (UFV), localizada no Município de Viçosa, Minas Gerais.

Foram utilizadas sementes de Eucalyptus grandis procedentes da Área de Produção de Sementes, localizada no Município de Mogi-Guaçu, São Paulo, da empresa International Paper do Brasil.

As sementes foram inicialmente lavadas seis vezes com água deionizada e, a seguir, manipuladas em câmara de fluxo laminar, onde foram desinfestadas com solução de álcool $70 \%$ por 30 seg e hipoclorito de sódio $5 \%$ durante $15 \mathrm{~min}$, sendo, então, enxaguadas por seis vezes com água deionizada e autoclavada.

A seguir, as sementes desinfestadas foram inoculadas em placas de Petri descartáveis estéreis (60 x $15 \mathrm{~mm}$; J. Prolab, Brasil) contendo $15 \mathrm{ml}$ de meio de cultura para germinação. Foi utilizado o meio de 
cultura MS (MURASHIGE e SKOOG, 1962) contendo a metade da concentração dos sais e vitaminas, $50 \mathrm{mg}$ $\mathrm{L}^{-1}$ de mio-inositol, 1,5\% de sacarose, $2,8 \mathrm{~g} \mathrm{~L}^{-1}$ de Phytagel $^{\circledR}$ (Sigma, USA), sendo o pH do meio ajustado para 5,7 $\pm 0,1$ e autoclavado por $15 \mathrm{~min}$. As placas foram vedadas com filme de PVC (Goodyear, Brasil) e as culturas, mantidas em sala de crescimento com temperatura de $27 \pm 2{ }^{\circ} \mathrm{C}$, fotoperíodo de $16 \mathrm{~h}$ na luz e $8 \mathrm{~h}$ no escuro e irradiância de $36 \mu \mathrm{mol} \mathrm{m}{ }^{-2} \mathrm{~s}^{-1}$ (fornecida por tubos fluorescentes, "Luz do dia”, Osram ${ }^{\circledR}, 20$ Watts), por um período de 7 a 10 dias, até completarem a germinação.

Como fonte de explantes foram utilizados os embriões zigóticos maduros (sementes desinfestadas inteiras), e das sementes germinadas in vitro foram obtidos os cotilédones totalmente expandidos (com aproximadamente 10 dias), os quais foram separados, retirando-se o meristema apical e segmentos de hipocótilos medindo cerca de 0,5 a 1,0 cm de comprimento.

Embriões zigóticos maduros, cotilédones e hipocótilos de $E$. grandis foram inoculados em placas de Petri descartáveis estéreis $(60$ x $15 \mathrm{~mm}$; J. Prolab, Brasil), contendo 15 mL de meio para indução de calos. O meio de indução foi composto por sais e vitaminas de MS, mioinositol (100 mg L $\left.{ }^{-1}\right)$, sacarose (3\%), Phytagel ${ }^{\circledR}\left(2,8 \mathrm{~g} \mathrm{~L}^{-1}\right)$ e com dicamba $\left(0,25 ; 0,5 ; 1,0\right.$; e $\left.2,0 \mathrm{mg} \mathrm{L}^{-1}\right)$ ou picloram $(0,5$; 1,$\left.5 ; 5,0 ; \mathrm{e} 10,0 \mathrm{mg} \mathrm{L}^{-1}\right)$. Nesse experimento, não se incluiu o controle $\left(0 \mathrm{mg} \mathrm{L}^{-1}\right)$, visto que em experimentos realizados anteriormente não ocorreu calejamento dos explantes na ausência de reguladores de crescimento no meio de indução.

$\mathrm{O} \mathrm{pH}$ do meio foi ajustado para 5,7 $\pm 0,1$ e o meio, autoclavado por $15 \mathrm{~min}$. As placas foram vedadas com filme de PVC (Goodyear, Brasil) e mantidas no escuro, em sala de crescimento com temperatura de $27 \pm 2{ }^{\circ} \mathrm{C}$, por um período de 30 dias, quando se avaliaram: o número de explantes calejados; a intensidade de calejamento; a oxidação; a rizogênese; o aspecto dos calos relacionados à textura e coloração; e a presença de estruturas embriogênicas.

O experimento foi montado segundo um esquema fatorial 4 x 3 (quatro concentrações de regulador de crescimento e três tipos de explante) no delineamento inteiramente casualizado com cinco repetições, sendo cada repetição composta por 15 explantes.

Após a avaliação aos 30 dias, calos originados em cotilédones e hipocótilos foram transferidos para dois meios de cultura distintos, sendo um deles o mesmo meio de indução e o outro o meio MS destituído de regulador de crescimento (MS0). Nos dois tratamentos, os calos permaneceram no escuro por mais uma semana, sendo posteriormente deixados em fotoperíodo de 16 $\mathrm{h}$ de luz e intensidade luminosa de $90 \mu \mathrm{mol} \mathrm{m} \mathrm{m}^{-2} \mathrm{~s}^{-1}$. Um segundo lote de calos contendo os mesmos tratamentos foi mantido somente no escuro. Tanto os calos que foram mantidos no claro quanto no escuro foram subcultivados novamente aos 30 dias para meio MS0 e mantidos nas mesmas condições de fotoperíodo ou escuro por mais 30 dias, quando foram realizadas novas observações.

Em outro experimento, calos induzidos em cotilédones e hipocótilos em meio contendo 0,5 e 1,0 $\mathrm{mg} \mathrm{L}^{-1}$ de dicamba, após 30 dias, foram subcultivados para meio contendo sais e vitaminas de MS, mio-inositol (100 mg L $\left.{ }^{-1}\right)$ e Phytagel $^{\circledR}\left(2,8 \mathrm{~g} \mathrm{~L}^{-1}\right)$, com os seguintes tratamentos: D1 = manutenção no mesmo meio de indução (dicamba - 0,5 e 1,0 $\mathrm{mg} \mathrm{L}^{-1}$ ); D2 = MS0 + 3\% sacarose $(\mathrm{p} / \mathrm{v}) ; \mathrm{D} 3=1 / 2 \mathrm{MS}+6 \%$ sacarose $+400 \mathrm{mg} \mathrm{L}^{-1} \mathrm{de} \mathrm{L}-$ glutamina; $\mathrm{D} 4=1 / 2 \mathrm{MS}+6 \%$ sacarose $+0,1 \mathrm{mg} \mathrm{L}^{-1}$ dicamba; $\mathrm{D} 5=1 / 2 \mathrm{MS}+6 \%$ sacarose $+0,1 \mathrm{mg} \mathrm{L}^{-1} \mathrm{ABA}$ (ácido abscísico); e D6 = 1/2 MS $+6 \%$ sacarose $+0,1 \mathrm{mg}$ $\mathrm{L}^{-1}$ dicamba $+0,1 \mathrm{mg} \mathrm{L}^{-1} \mathrm{ABA}$.

As culturas foram mantidas no escuro, em sala de crescimento com temperatura de $27 \pm 2{ }^{\circ} \mathrm{C}$; aos 60 dias foram avaliadas a coloração e a textura dos calos, a rizogênese e a presença de estruturas embriogênicas. O experimento foi montado segundo um esquema fatorial $2 \times 6 \times 2$ (dois tratamentos de indução, seis tratamentos de subcultivo e dois tipos de explante) no delineamento inteiramente casualizado, com três repetições e cinco explantes por repetição.

Estruturas semelhantes a embriões somáticos, obtidas no tratamento com $0,5 \mathrm{mg} \mathrm{L}^{-1}$ de dicamba, foram isoladas e fixadas em $\mathrm{FAA}_{50}$, durante $24 \mathrm{~h}$ no dessecador, sob vácuo, e estocadas em etanol $70 \%$. As amostras foram desidratadas em série etílica e incluídas em metacrilato (Historesin, Leica), preparado conforme a instrução do fabricante. Os blocos foram cortados longitudinalmente ( $5 \mu \mathrm{m}$ de espessura) em micrótomo rotativo de avanço automático (RM 2155 - Leica), com a utilização de navalhas de aço descartáveis.

Os cortes das amostras incluídas em metacrilato foram corados com Azul de Toluidina em $\mathrm{pH}$ ácido, para detectar radicais aniônicos e metacromasia

R. Árvore, Viçosa-MG, v.31, n.3, p.417-426, 2007 
(O'BRIEN e MCCULLY, 1981), e as lâminas foram montadas em resina sintética (Permount ${ }^{\circledR}$ ).

As observações e a documentação fotográfica foram realizadas no Laboratório de Anatomia Vegetal do Departamento de Biologia Vegetal da UFV, utilizando um fotomicroscópio de luz Olympus (AX70), equipado com um sistema U-Photo (Image Proplus).

\section{RESULTADOS E DISCUSSÃO}

Explantes originados de embriões zigóticos maduros iniciaram o processo de germinação em um período de três a cinco dias após a inoculação, em meio com regulador de crescimento. Em todas as concentrações de dicamba houve intensa proliferação de gemas apicais e rizogênese. Os calos formados foram de coloração amarelo-clara a branca e de textura semifriável; no entanto, o calejamento foi muito baixo, e sua observação foi dificultada pela presença de gemas e raízes. Já os calos formados em meio com picloram foram de coloração amarelo-escura, de textura semifriável a semicompacta nas concentrações de 0,5 e $1,0 \mathrm{mg} \mathrm{L}^{-1}$ e mucilaginosos nas concentrações de 5,0 e $10,0 \mathrm{mg} \mathrm{L}^{-1}$. A rizogênese foi menos intensa, em comparação com os tratamentos com dicamba. Não foram observadas estruturas embriogênicas em nenhuma das concentrações dos dois reguladores de crescimento.

Embriogênese somática a partir de embriões zigóticos maduros de E. citriodora foi obtida por Muralidharan e Mascarenhas (1987; 1995), após a remoção dos tegumentos e utilizando 3-5 $\mathrm{mg} \mathrm{L}^{-1} \mathrm{de}$ ANA. Em E. dunnii, Termignoni et al. (1996) constataram a formação de setores embriogênicos em plântulas com três dias de germinação em meio contendo ANA ou ANA/2,4-D, nas proporções de 1:1 e 3:1. Pinto et al. (2002) observaram embriogênese somática em E. globulus em calos derivados de embriões zigóticos maduros inteiros na presença de 3-15 mg L $\mathrm{m}^{-1}$ de ANA isoladamente ou na combinação de $1 \mathrm{mg} \mathrm{L}^{-1}$ de ANA com $1 \mathrm{mg} \mathrm{L}^{-1}$ de 2,4-D.

Em cotilédones e hipocótilos, a formação de calos iniciou a partir de uma semana após a inoculação. $\mathrm{O}$ calejamento total em dicamba aos 30 dias foi próximo de $100 \%$, em todos os tratamentos e nos dois tipos de explantes (Figura 1). Em cotilédones, a intensidade de calejamento aumentou progressivamente com o incremento da concentração de dicamba. À exceção da concentração de $0,25 \mathrm{mg} \mathrm{L}^{-1}$, em todos os tratamentos os maiores porcentuais de calejamento (acima de 50\%) foram observados na classe de intensidade média. Já em hipocótilos, em todas as concentrações, acima de $80 \%$ dos explantes apresentaram intensidade baixa de calejamento.

\section{Cotilédones}

Baixa on Média uAlta

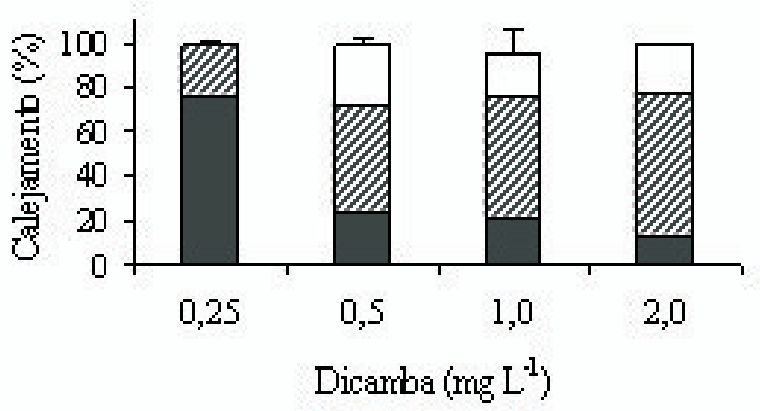

Hipocótilos

Baixa Ø Média $\square$ Alta

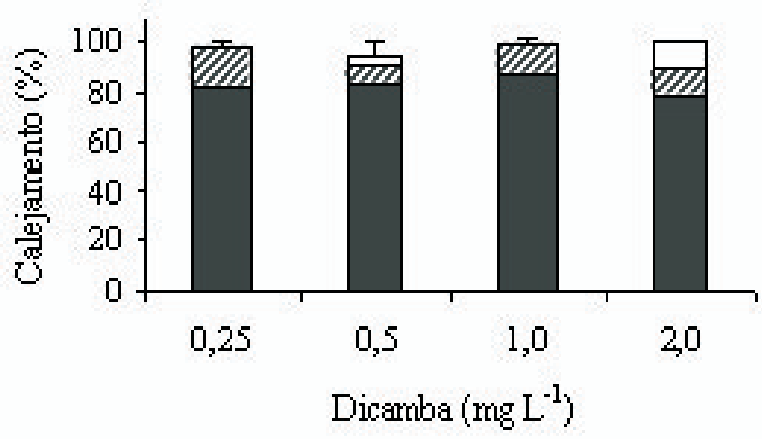

Figura 1 - Porcentual e intensidade de calejamento em função das concentrações de dicamba em cotilédones e hipocótilos de Eucalyptus grandis, aos 30 dias de permanência no escuro. As barras indicam o desviopadrão em relação ao calejamento total de cada concentração de dicamba.

Figure 1-Percentage and intensity of callusing as a function of dicamba concentrations in cotyledons and hypocotils of Eucalyptus grandis, after 30 days in dark. Bars indicate standard deviation of total callusing for each dicamba concentration. 
O calejamento ocorreu na região abaxial de cotilédones e nas extremidades e superfície dos hipocótilos. Nos dois tipos de explante, os calos formados apresentaram coloração amarelo-clara ou branca e de textura semicompacta, tendendo à friabilização. Na concentração de $0,5 \mathrm{mg} \mathrm{L}^{-1}$ de dicamba, observou-se a formação de calo com regiões contendo agrupamentos celulares, assemelhando-se a embriões em estádio globular a cordiforme (Figura 3A). Nos tratamentos de 1,0 e $2,0 \mathrm{mg} \mathrm{L}^{-1}$, em hipocótilos, foram observados calos mucilaginosos, sem organização e com algumas regiões escurecidas, de coloração cinza-escura. Esse escurecimento também ocorreu em cotilédones no tratamento de 2,0 $\mathrm{mg} \mathrm{L}^{-1}$. Rizogênese de intensidade baixa a média foi observada em todos os tratamentos, sendo reduzida com o aumento da concentração de dicamba. A oxidação fenólica foi praticamente nula.

Aos 30 dias em meio de indução, em um explante no tratamento com $0,5 \mathrm{mg} \mathrm{L}^{-1}$ de dicamba foram observadas estruturas que se destacavam por apresentar formato semelhante a embriões em estádio cordiforme a torpedo, de coloração amarelo-clara a creme (Figura 3BC), diferenciando-se das demais regiões do calo. O calo que apresentou tais estruturas foi transferido para meio MS0 e permaneceu nesse meio e no escuro por mais 30 dias. Posteriormente, cinco estruturas foram facilmente isoladas para estudo anatômico.

Nos tratamentos com picloram aos 30 dias, o calejamento total em cotilédones foi próximo de $100 \%$ em todos os tratamentos, com exceção do tratamento de $0,5 \mathrm{mg} \mathrm{L}^{-1}$ (Figura 2). Em todas as concentrações, o calejamento foi de intensidade baixa e média. No início do calejamento, os calos apresentaram-se com coloração amarelo-escura e textura semifriável; no entanto, posteriormente, foram-se tornando acinzentados. Sobre as regiões acinzentadas dos calos formados em cotilédones nas concentrações de 5,0 e 10,0 mg L-1, foram observadas regiões de calos de coloração cinzaclara ou branco-leitosa, com aspecto semelhante a embriões somáticos em estádio globular (Figura 3D).

Em hipocótilos, o porcentual de calejamento foi reduzindo-se com o aumento das concentrações de picloram, e a intensidade de calejamento foi baixa em todos os tratamentos. Em todas as concentrações, observaram-se calos sem consistência, de textura mucilaginosa e coloração cinza-escura.

\section{Cotilédones}

Baixa Ø Média 口Alta

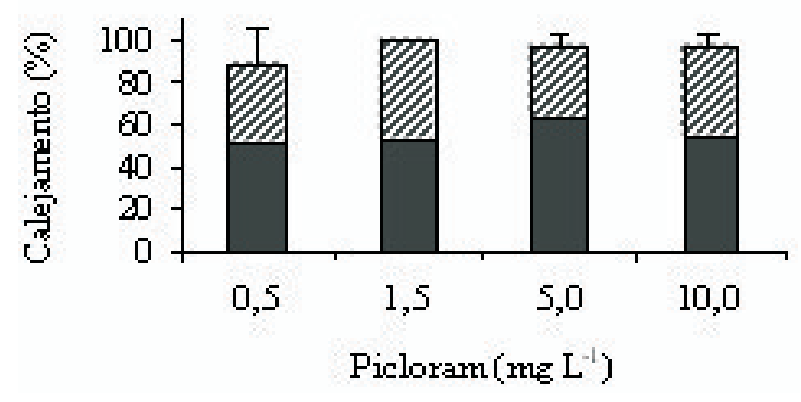

Hipocótilos

$\square$ Baixa v Média $\square$ Alta

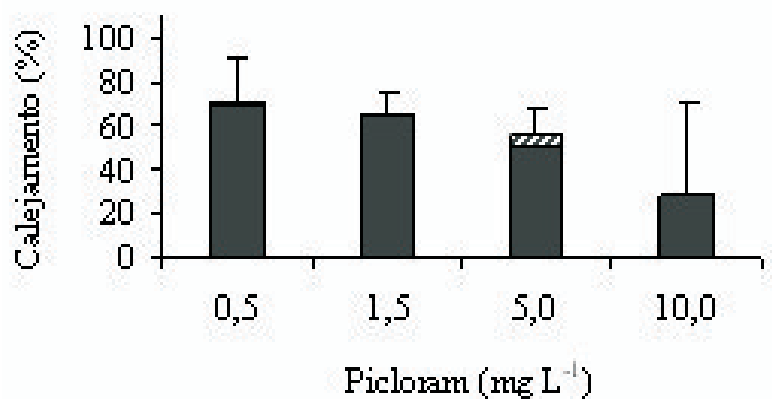

Figura 2 - Porcentual e intensidade de calejamento em função das concentrações de picloram em cotilédones e hipocótilos de Eucalyptus grandis, aos 30 dias de permanência no escuro. As barras indicam o desviopadrão em relação ao calejamento total de cada concentração de picloram.

Figure 2-Percentage and intensity of callusing as a function of picloram concentrations in cotyledons and hypocotils of Eucalyptus grandis, after 30 days in dark. Bars indicate standard deviation of total callusing for each picloram concentration.

A regeneração direta de embriões somáticos de Eucalyptus não tem sido reportada com freqüência, sendo relatada até o momento somente em $E$. citriodora (MURALIDHARAN e MASCARENHAS, 1995) e $E$. globulus (NUGENT et al., 2001; PINTO et al., 2002). Nos outros trabalhos, embriogênese somática ocorreu com prévia formação da fase de calo. Diversos tipos de calo foram citados, os quais posteriormente

R. Árvore, Viçosa-MG, v.31, n.3, p.417-426, 2007 
regeneraram embriões somáticos. Nugent et al. (2001) obtiveram calos soltos, macios e tendendo a acumular fenóis em poucas semanas após o início do calejamento. Calos embriogênicos em outras espécies de Eucalyptus são descritos como de coloração marrom, com setores nodulares de cor branca (TERMIGNONI et al., 1996), friáveis e brancos (BOULAY, 1987, citado por NUGENT et al., 2001), de coloração creme e nodulares ou acinzentados e macios (FURZE, 1988, citado por NUGENT et al., 2001). Similarmente, Blakeway et al. (1993) descreveram calos com células embriogênicas de $E$. grandis de cor creme a branca ou marrom, sendo macios ou nodulares.
Calos formados em cotilédones nas concentrações de 5,0 e 10,0 $\mathrm{mg} \mathrm{L}^{-1}$ de picloram, quando subcultivados em meio MS0 e mantidos no claro, apresentaram estruturas semelhantes a embriões somáticos em estádio de torpedo e cotiledonar (Figura 3EF). Essas estruturas foram formadas sobre regiões escurecidas de dois calos (sendo um em cada tratamento) e isoladas facilmente quando manipuladas com o auxílio de uma pinça. No entanto, essas estruturas não se desenvolveram após serem isoladas. Também, pelo fato de serem em número reduzido, não foi possível a realização de análise histológica para confirmação dos padrões celulares obtidos.
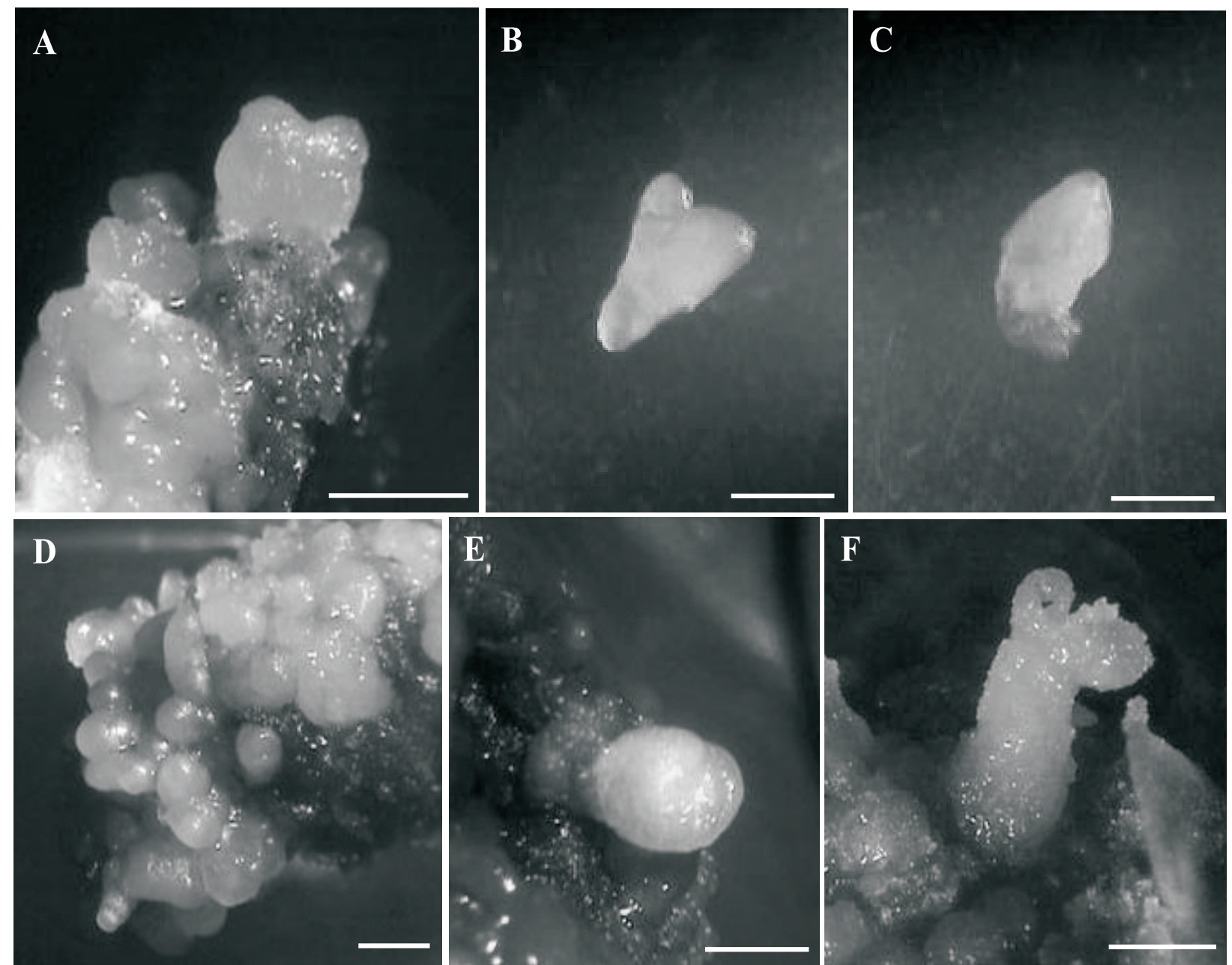

Figura 3 - Formação de estruturas semelhantes a embriões somáticos em Eucalyptus grandis. Estruturas formadas em 0,5 $\mathrm{mg} \mathrm{L}^{-1}$ de dicamba (A-C) e em 5,0 e 10,0 $\mathrm{mg} \mathrm{L}^{-1}$ de picloram (D-F). Barras $=1 \mathrm{~mm}$.

Figure 3 - The development of embryo-like structure in Eucalyptus grandis in vitro culture. Structure developed in 0.5 $m g L^{-1}$ dicamba $(A-C)$ and 5 and $10 \mathrm{mg} \mathrm{L}^{-1}$ picloram $(D-F)$. Bars $=1 \mathrm{~mm}$.

R. Árvore, Viçosa-MG, v.31, n.3, p.417-426, 2007

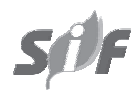


Embriogênese somática em Eucalyptus tem sido alcançada, geralmente, com a utilização de tratamentos com ANA e 2,4-D, isoladamente ou em combinação (MURALIDHARAN e MASCARENHAS, 1995; TERMIGNONI et al., 1996; PINTO et al., 2002). Particularmente para E. grandis, embriões somáticos foram obtidos somente na presença de 2,4-D (WATT et al., 1991, 1999).

Diversos autores relataram a utilização de dicamba e picloram na indução de embriogênese somática em espécies agronômicas (GEORGE, 1993; DINESHKUMAR et al., 1995; LEE et al., 1997; CHARRIÈRE e HAHNE, 1998; CASTILLO etal., 2000; LITTLE etal., 2000; SUZUKI et al., 2002; AKUTSU e SATO, 2002; KAUR e KOTHARI, 2004). O picloram é usado para induzir e, ou, manter calos ou cultura de suspensão em plantas de folhas largas, ou para induzir a formação de calos embriogênicos, em que pode ser mais efetivo que 2,4-D. A concentração requerida (em torno de 0,01-1,0 $\mathrm{mg} \mathrm{L}^{-1}$ ) é, geralmente, menor que a necessária para outras auxinas (GEORGE, 1993). Calos embriogênicos foram induzidos em lírio (Agapanthus praecox) e mantidos, através de subcultivos mensais, em meio MS contendo $1,0 \mathrm{mg} \mathrm{L}^{-1}$ de picloram. Numerosos embriões somáticos foram produzidos, os quais originaram plantas após a transferência para meio livre de regulador de crescimento (SUZUKI et al., 2002). O dicamba é freqüentemente efetivo na indução e formação de calos embriogênicos em monocotiledôneas. O uso de 2,0 $\mathrm{mg} \mathrm{L}^{-1}$ permitiu a formação de calos em trigo, os quais, posteriormente, produziram maior quantidade de embriões em conjunto com 0,5 - 1,0 mg $\mathrm{L}^{-1}$ de cinetina (6-furfurilaminopurina) do que aqueles induzidos a uma concentração ótima de $0,8 \mathrm{mg} \mathrm{L}^{-1} \mathrm{de}$ 2,4-D (CARMAN et al., 1988, citados por GEORGE, 1993). Provavelmente, isso ocorreu porque o dicamba é metabolizado rapidamente em trigo, possivelmente mais rápido que o 2,4-D (GEORGE, 1993).

Referindo-se às espécies florestais, trabalhos que abordam a utilização dessas auxinas são escassos; contudo, Nugent et al. (2001) obtiveram embriões somáticos em estádio cotiledonar a partir de calos embriogênicos formados em fragmentos de cotilédones e hipocótilos de embriões zigóticos maduros de $E$. globulus em tratamentos com $12,0 \mathrm{mg} \mathrm{L}^{-1}$ de picloram. Arruda et al. (2000) relataram a formação de embriões somáticos em estádio globular em meio de indução de calos contendo 5,0 $\mathrm{mg} \mathrm{L}^{-1}$ de picloram. Pinto et al. (2002) utilizaram $0,5 \mathrm{mg} \mathrm{L}^{-1}$ de dicamba sozinho ou associado com 1,0 $\mathrm{mg} \mathrm{L}^{-1}$ de zeatina [N-(4-hidroxi-3metilbut-2-enil) aminopurina] na indução de calos em E. globulus, porém não obtiveram sucesso na formação de embriões somáticos com esses tratamentos.

Com exceção das estruturas semelhantes a embriões que foram isoladas, os calos obtidos nos tratamentos com dicamba e picloram que foram mantidos por mais de 30 dias em meio com regulador de crescimento ou em MS0, tanto em condições de escuro quanto em fotoperíodo, tornaram-se mais compactos e oxidados com o passar dos dias. Nenhuma estrutura embriogênica foi observada posteriormente.

Os calos induzidos em 0,5 e 1,0 $\mathrm{mg} \mathrm{L}^{-1}$ de dicamba que foram transferidos para os tratamentos de subcultivo, após 60 dias, apresentaram-se bastante compactos e escurecidos e com intensa formação de raízes. Em geral, os calos formados em cotilédones mostraram-se mais compactos e oxidados do que em hipocótilos. Não foi constatada variação de resposta em relação aos tratamentos utilizados. Também, não foram observadas estruturas embriogênicas.

O estudo anatômico realizado com as estruturas observadas nos tratamentos com dicamba mostrou tratarse de estruturas independentes, evidenciando-se a presença de um sistema vascular fechado (Figura 4AB). Foram observadas três regiões distintas, sendo a mais externa semelhante a uma protoderme, formada por células achatadas $(\mathrm{Pd})$, uma região central com células alongadas semelhantes às de procâmbio $(\mathrm{Pc})$ e uma região intermediária formada por células parenquimáticas (Par). No entanto, nessas estruturas não foi visualizada claramente a presença dos meristemas apicais. Em algumas regiões, verificou-se a ocorrência de degeneração celular, sendo observado descolamento das células parenquimáticas e destacamento da protoderme, o que pode ser devido, principalmente, à inadequação do meio de cultura, principalmente em relação aos reguladores de crescimento. Nessa região em degeneração, através da reação metacromática do Azul de Toluidina, notou-se a presença de compostos fenólicos (Fe), os quais adquirem coloração verde-azulada.

As estruturas semelhantes a embriões somáticos obtidas neste trabalho não mostraram claramente o desenvolvimento de meristemas apicais, assim como também esses resultados não foram reproduzíveis com freqüência definida. Segundo Nugent et al. (2001), embriões somáticos de E. globulus induzidos em picloram

R. Árvore, Viçosa-MG, v.31, n.3, p.417-426, 2007 
e ácido indolbutírico (AIB) mostraram polaridade; todavia, os cotilédones e os ápices caulinar e radicular foram pouco desenvolvidos, e os resultados obtidos não apresentaram repetibilidade, fato comumente relatado para o gênero Eucalyptus.
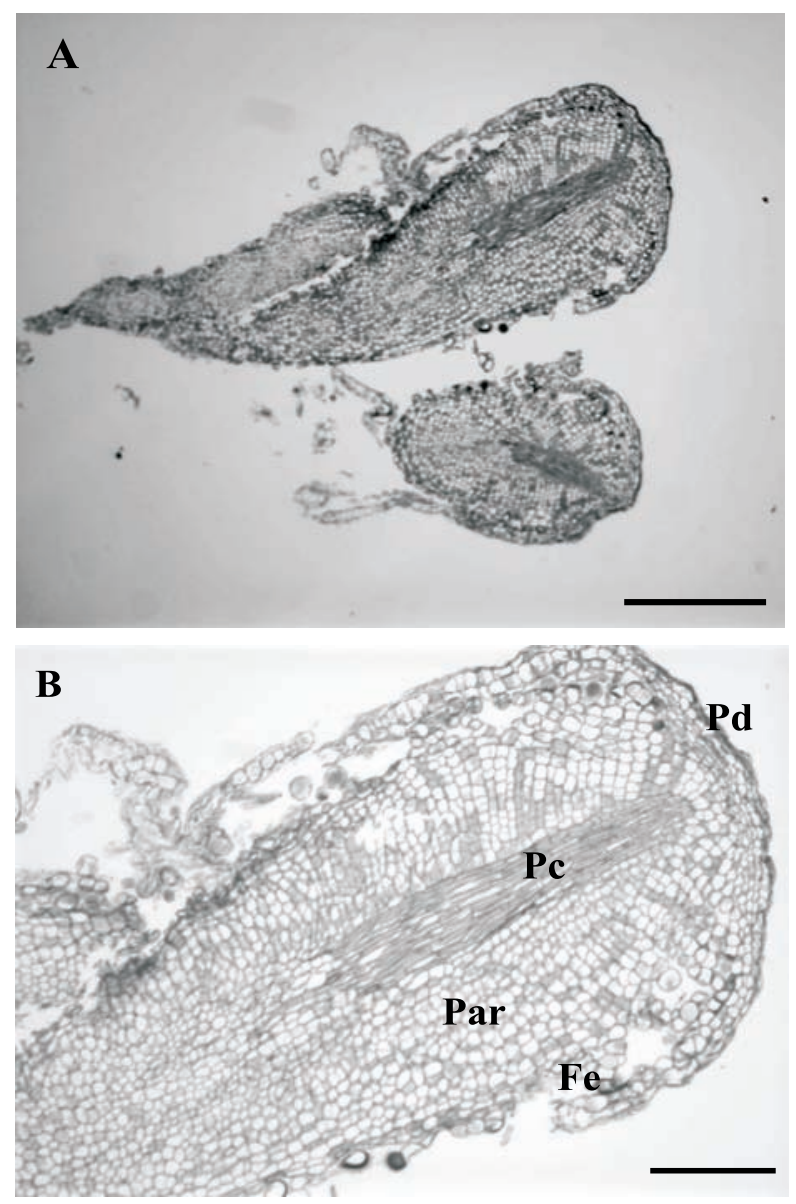

Figura 4 - Secção longitudinal de estruturas semelhantes a embriões somáticos de Eucalyptus grandis corados com Azul de Toluidina. A) estruturas independentes com sistema vascular fechado. Barra $=450 \mu \mathrm{m}$. B) detalhe do embrião sugerindo a presença de protoderme $(\mathrm{Pd})$, procâmbio $(\mathrm{Pc})$, células parenquimáticas (Par) e de uma região em degeneração com a presença de compostos fenólicos ( $\mathrm{Fe}$ ). Barra $=150 \mu \mathrm{m}$.

Figure 4-Longitudinal section of Eucalyptus grandis embryolike structure stained in toluidine blue. A) Independent structures with closed vascular system. Bar $=450$ $\mu \mathrm{m} . \mathrm{B})$ Detailed embryo section suggesting the presence of protoderm $(P d)$, procambium $(P c)$, parenchyma cells (Par) and a degenerating region rich in phenolic compounds (Fe). Bar $=150 \mu \mathrm{m}$.
Formação de embriões somáticos anormais, baixa freqüência de regeneração, falta de sincronização no desenvolvimento, não-conversão desses embriões em plantas e não-repetibilidade dos resultados são grandes entraves que têm limitado a obtenção de um protocolo eficiente de embriogênese somática para Eucalyptus grandis e outras espécies do gênero. Estratégias de pesquisa têm sido desenvolvidas para a superação desses obstáculos, assim como para a produção de culturas embriogênicas de árvores adultas, em adição àquelas desenvolvidas para material juvenil.

Com a otimização dos protocolos e a confirmação da uniformidade genética, a embriogênese somática, aliada às técnicas de clonagem de Eucalyptus utilizadas atualmente em escala comercial, apresenta grande potencial para rejuvenescimento de material selecionado de difícil enraizamento, assim como na regeneração de plantas transformadas geneticamente. Uma vez obtidas essas plantas, o material pode ser multiplicado em grande escala pela técnica da microestaquia (XAVIER e COMÉRIO, 1996; TITON et al., 2003), já bastante difundida nas empresas florestais.

\section{CONCLUSÃO}

Os resultados do presente trabalho indicaram que as auxinas dicamba e picloram são promissoras no desenvolvimento de um protocolo de embriogênese somática para Eucalyptus grandis.

Os melhores resultados foram obtidos com a utilização de $0,5 \mathrm{mg} \mathrm{L}^{-1}$ de dicamba ou 5,0 e 10,0 $\mathrm{mg} \mathrm{L}^{-1}$ de picloram, utilizando-se explantes cotiledonares de plântulas germinadas in vitro com 10 dias de idade.

\section{AGRADECIMENTOS}

Ao Conselho Nacional de Desenvolvimento Científico e Tecnológico-CNPq, pelo apoio financeiro concedido, e à International Paper do Brasil, pelo fornecimento do material genético (sementes).

\section{REFERÊNCIAS}

AKUTSU, M.; SATO, H. Induction of proembryos in liquid culture increases the efficiency of plant regeneration from Alstroemeria calli. Plant Science, v.163, p.475-479, 2002. 
ARRUDA, S. C. C. et al. Anatomical and biochemical characterization of the calcium effect on Eucalyptus urophylla callus morphogenesis in vitro. Plant Cell, Tissue and Organ Culture, v.63, p.143-154, 2000.

BAJAJ, Y. P. S. (Ed.). Somatic embryogenesis and synthetic seed $I$. Biotechnology in agriculture and forestry. New York: Springer-Verlag, 1995.v.30. 472p.

BANDYOPADHYAY, S. et al. Efficient plant regeneration from seedling explants of two commercially important temperate eucalypt species - Eucalyptus nitens and E. globulus. Plant Science, v.140, p.189-198, 1999.

BANDYOPADHYAY, S.; HAMILL, J. D. Ultrastructural studies of somatic embryos of Eucalyptus nitens and comparisons with zygotic embryos found in mature seeds. Annals of Botany, v.86, p.237-244, 2000.

BLAKEWAY, F. C.; HERMAN, B.; WATT, M. P. Establishment of cell suspension cultures of Eucalyptus grandis and E. grandis $\mathrm{x}$ camaldulensis. Southern African Forestry Journal, v.166, p.17-26, 1993.

CASTILLO, P. et al. Plant regeneration from callus and suspension cultures of Valeriana edulis ssp. procera via simultaneous organogenesis and somatic embryogenesis. Plant Science, v.151, p.115-119, 2000.

CHARRIÈRE, F.; HAHNE, G. Induction of embryogenesis versus caulogenesis on in vitro cultured sunflower (Helianthus annuus L.) immature zygotic embryos: role of plant growth regulators. Plant Science, v.137, p.63-71, 1998.

DINESHKUMAR, V. et al. Picloram induced somatic embryogenesis in chickpea (Cicer arietinum L.). Plant Science, v.109, p.207-213, 1995.

DURZAN, D. J. Somatic polyembryogenesis for the multiplication of tree crops.

\section{Biotechnology Genetics Engineering}

Review, v.6, p.339-376, 1988.

GEORGE, E. F. Plant propagation by

tissue culture - The technology. 6 ed.

England: Exegetics, 1993. v.1.575p.
GUERRA, M. P.; TORRES, A. C.; TEIXEIRA, J. B. Embriogênese somática e sementes sintéticas. In: TORRES, A. C.; CALDAS, L. S.; BUSO, J. A. (Ed.). Cultura de tecidos e transformação genética de plantas. Brasília: Embrapa-SPI/EmbrapaCNPH, 1999. v.2. p.533-568.

HAINES, R. J. Mass propagation by cuttings, biotechnologies and the capture of genetic gain. In: MASS PRODUCTION TECHNOLOGY FOR GENETICALLY IMPROVED FAST GROWING FOREST TREE SPECIES, 1992, Bordeaux. Proceedings... Paris: AFOCEL/ IUFRO, 1992. p.137-150.

JIMÉNEZ, V. M. Regulation of in vitro somatic embryogenesis with emphasis on the role of endogenous hormones. Revista Brasileira de Fisiologia Vegetal, v.13, n.2, p.196-223, 2001.

KAUR, P.; KOTHARI, S. L. In vitro culture of kodo millet: influence of 2,4-D and picloram in combination with kinetin on callus initiation and regeneration. Plant Cell, Tissue and Organ Culture, v.77, p.73-79, 2004.

LEE, K. S. et al. Histology of somatic embryo initiation and organogenesis from rhizome explants of Musa spp. Plant Cell, Tissue and Organ Culture, v.51, p.1-8, 1997.

LITTLE, E. L.; MAGBANUA, Z. V.; PARROTT, W. A. A protocol for repetitive somatic embryogenesis from mature peanut epicotyls. Plant Cell Reports, v.19, p.351-357, 2000.

MAJOR, G. et al.. Preliminary studies on the somatic embryogenesis in Eucalyptus grandis. In: IUFRO CONFERENCE ON SILVICULTURE AND IMPROVEMENT OF EUCALYPTS, 1997, Salvador. Proceedings... Colombo: Embrapa, 1997. v. 1. p.137-142.

MURALIDHARAN, E. M.; MASCARENHAS, A. F. In vitro plantlet formation by organogenesis in Eucalyptus camaldulensis and by somatic embryogenesis in E. citriodora. Plant Cell Reports, v.6, p.256-259, 1987.

R. Árvore, Viçosa-MG, v.31, n.3, p.417-426, 2007 
MURALIDHARAN, E. M.; MASCARENHAS, A. F. Somatic embryogenesis in Eucalyptus. In: JAIN, S. M.; GUPTA, P. K.; NEWTON, R. J. (Ed.). Somatic embryogenesis in woody plants. Dordrecht: Kluwer Academic Publishers, 1995.v.2. p.23-40.

MURASHIGE, T.; SKOOG, F. A revised medium for rapid growth and bioassays with tobacco tissue cultures. Physiologia Plantarum, v.15, p.473-497, 1962.

NUGENT, G.et al. Somatic embryogenesis in Eucalyptus globulus. Plant Cell, Tissue and Organ Culture, v.67, p.85-88, 2001.

O'BRIEN, T.; MCCULLY, M. E. The study of plant structure principles and selected methods. Melbourne: Temarcarphi Pty, 1981. 45p.

PINTO, G. et al.Somatic embryogenesis and plant regeneration in Eucalyptus globulus Labill. Plant Cell Reports, v.21, n.3, p.208-213, 2002.

RUAUD, J. N.; CHURCHILL, K.; PEPPER, S. Somatic embryogenesis initiation in Eucalyptus nitens. Acta Horticulturae, v.447, p.185-186, 1997.

SUZUKI, S.; OOTA, M.; NAKANO, M. Embryogenic callus induction from leaf explants of the Lilliaceous ornamental plant, Agapanthus praecox ssp. Orientalis (Leighton) Leighton. Histological study and response to selective agents. Scientia Horticulturae, v.95, p.123-132, 2002.

R. Árvore, Viçosa-MG, v.31, n.3, p.417-426, 2007
TERMIGNONI, R. R.; WANG, P.; HU, C. Somatic embryo induction in Eucalyptus dunnii. Plant Cell, Tissue and Organ Culture, v.45, p.129-132, 1996.

TIBOK, A. et al. Optimized plant regeneration from callus derived from seedling hypocotyls of Eucalyptus urophylla. Plant Science, v.110, p.139-145, 1995.

TITON, M.; XAVIER, A.; OTONI, W. C. Efeito do AIB no enraizamento de miniestacas e microestacas de clones de Eucalyptus grandis W. Hill ex Maiden. Revista Árvore, v.27, n.1, p.1-7, 2003.

VICIENT, C. M.; MARTINEZ, F. X. The potential uses of somatic embryogenesis in agroforestry are not limited to synthetic seed technology.

Revista Brasileira de Fisiologia Vegetal, n.10, v.1, p.1-12, 1998.

WATT, M. P. et al. Somatic embryogenesis in Eucalyptus grandis. South African Forestry Journal, v.157, p.59-65, 1991.

WATT, M. P. et al. Somatic embryogenesis in Eucalyptus grandis e E. dunnii. In: JAIN, S. M.; GUPTA, P. K.; NEWTON, R. J. (Ed.). Somatic embryogenesis in woody plants, Dordrecht: Kluwer Academic Publishers, 1999. v.5. p.63-78.

XAVIER, A.; COMÉRIO, J. Microestaquia: uma maximização da micropropagação de Eucalyptus. Revista Árvore, v.20, n.1, p.9-16, 1996. 